\title{
Prevalence of work related musculoskeletal disorders in brick industry workers in Chilaw Sri Lanka
}

Fernando $\mathrm{WIB}^{1}$, De Silva $\mathrm{PV}^{2}$ and Sundarapperuma SMTD ${ }^{1}$

\section{Abstract}

Background Brick industry is an oldest industry in Sri Lanka. Brick making process includes different actions which can lead to musculoskeletal disorders. Studies have been carried out in brick industries and shown that brick making process leads to musculoskeletal disorders.

Objectives To determine the prevalence of work related musculoskeletal disorders among brick workers by identifying the most affected body regions and the joints and specific ergonomic risk factors in work place, explore associated factors, and the effect of musculoskeletal disorders to daily living,

Materials and methods Using descriptive cross sectional study and an interviewer administered questionnaire, data were collected from 192 brick industry workers who were in the industry for more than 1 year in Chilaw Area, Puttlam district.

Results The study consisted with 130 males and 62 females. Majority of $85.9 \%$ of workers were having a normal BMI and $65.6 \%$ of the participants were having pain and discomfort lasting at least 24 hours during last 12 months, while $39.6 \%$ of them were having low back pain where $0.5 \%$ having neck pain. A majority (82.5\%) was prevented from doing the normal work activities at home or away from home because of a musculoskeletal pain or a discomfort. Majority $(77.0 \%)$ of participants applies a local analgesic to relieve the pain. $27 \%$ of the workers were holding loads for distances where $73.8 \%$ of the workers lifts their loads manually.

Conclusion Work related musculoskeletal disorder are prevalent among brick workers and the most commonly affected body regions are low back, wrists/ hands, shoulders, knees, neck, elbows and ankles/feet. There is no any significant difference with the age and sex with the presence of musculoskeletal discomfort or pain in this study sample. These MSDs are affecting the activities of daily living of workers by preventing from normal activities.

\footnotetext{
${ }^{1}$ Nursing Degree Programme, Faculty of Medicine, University of Ruhuna, Sri Lanka.

2 Department of Community Medicine, Faculty of Medicine, University of Ruhuna, Sri Lanka.
}

\section{Introduction}

Brick industry is one of the most important and oldest industries in Sri Lanka where thousands of workers engaged in. Due to low socio economic status and poor educational status, people who are in rural areas are involved in this industry. At the cottage and village levels, the technology, in general, is simple, bricks are hand-molded, sun dried and then fired in a kiln. Brick industry includes different unfavorable actions and these actions can lead to various types of musculoskeletal disorders in the body, especially in low back, knee, shoulders, neck and wrist. Globally, musculoskeletal disorders is the largest single cause of work-related illness, accounting for over $33 \%$ of all newly reported occupational illnesses in the general population and $77 \%$ in construction workers. [1] This class of disease is among the most common in the world, affecting individuals of all ages, sex, socioeconomic classes, and ethnicities.[2] In contrast to other occupational disorders which could be attributed to occupational exposures to toxic substances, Work related musculoskeletal disorders(WMSDs) among brick workers owes its pathophysiology to unorthodox postures opted by these workers, where the joints and muscles are held in conducive physiological positions for protracted periods of time, in suboptimal working conditions. [3] Also occupational risk factors for low back pain include forceful lifting, bending and twisting of the trunk and heavy manual labor.[4]

Results of the research studies on brick industry shows that the respondents reported having experienced pain/ discomfort arising from work, with the body parts most commonly affected being the low back, followed by the wrists/hands, shoulders, and neck. The respondents consistently identified factors such as frequent twisting and bending of the trunk as the leading cause of the pain/discomfort.

This study was performed to investigate WMSDs within unorganized brick-making units in Chiaw Area, Puttlam District, Sri Lanka. The study is focused from the initial steps of brick making to the end procedures, including mining, preparation, and molding of clay, followed by drying and burning of bricks and transportation.

\section{Materials and methods}

This descriptive cross sectional was carried out in the rural areas of Chilaw, Puttlam District, Sri Lanka where 
brick industry is a cottage industry mostly the entire family is involved to sustain their livelihood. One hundred and ninety two participants who have been in the industry for more than one year were included for the study after an initial verbal explanation and getting the written informed consent for the participation followed by an interview which lasted 20 minutes in a confidential place during the working time, through which the questionnaires were filled. The questionnaire was an pre tested interviewer administered modified Nordic Style questionnaire [5] which contained open ended and close ended questions regarding the Socio demographic data, Occupational data, Data on Musculoskeletal symptoms, hazard identification and substance usage. When considering the musculoskeletal symptoms, the most worsen area of pain or discomfort was considered among the multiple pain areas. Data were analyzed by using descriptive statistics including mean and Standard Deviation(SD) and data is presented by percentages, as well as results are displayed on each variable by appropriate diagrams like bar charts, using Statistical Package of Social Science (SPSS) version 15.0 as data analysis tool. Pearson's chi square test was used to assess the association between categorical variables. Statistical significance was set at $p<0.05$. This study was approved form the Ethical Review Committee of the Faculty of Medicine, University of Ruhuna.

\section{Results}

The brick workers were from the rural areas of Chilaw, Puttlam District, Sri Lanka and there was a male predominance (67.7\%). Their ages ranged from 22 to 70 with the mean of $51.54(S D=10.344)$ years and majority of participants (72.9\%) represents the $41-60$ age group while $5.2 \%$ represents the $18-25$ age group. Majority (87.5\%) were Sinhalese. Only $2.1 \%$ of the participants were in the grade 9-10 category. Most of them $(59.4 \%)$ were studied below grade 8 . But nearly half of the study population were literate (53.1\%). Their weights were ranged from 46 to $60 \mathrm{~kg}$, with a mean of $52.39 \mathrm{~kg}(\mathrm{SD}=3.274)$ and there were majority of $85.9 \%$ of participants in the normal weight category and only $10.4 \%$ of participants were undernourished. There was $65.1 \%$ of the population without any medical conditions and the remaining (34.9\%) was reported as having non communicable diseases such as diabetes mellitus and hypertension. (Table 01)
Table 01 demographic profile $(\mathrm{N}=192)$

\begin{tabular}{|c|c|c|c|}
\hline Characteristics & Categories & Frequency & Percentage \\
\hline \multirow[t]{2}{*}{ Gender } & Male & 130 & 67.7 \\
\hline & Female & 62 & 32.3 \\
\hline \multirow[t]{4}{*}{ Age in years } & $18-25$ & 10 & 5.2 \\
\hline & $26-40$ & 17 & 8.9 \\
\hline & $41-60$ & 140 & 72.9 \\
\hline & $61-75$ & 25 & 13.0 \\
\hline \multirow[t]{2}{*}{ Ethnicity } & Sinhalese & 168 & 87.5 \\
\hline & Tamil & 24 & 12.5 \\
\hline \multirow[t]{4}{*}{ Religion } & Buddhism & 99 & 51.6 \\
\hline & Catholicism & 69 & 35.9 \\
\hline & Islamic & 3 & 1.6 \\
\hline & Hindu & 21 & 10.9 \\
\hline \multirow[t]{5}{*}{ Marital status } & Married & 130 & 67.7 \\
\hline & Unmarried & 21 & 10.9 \\
\hline & Widowed & 16 & 8.3 \\
\hline & Separated & 23 & 12.0 \\
\hline & Divorced & 2 & 1.0 \\
\hline \multirow{3}{*}{$\begin{array}{l}\text { Educational } \\
\text { status }\end{array}$} & Grade 1-5 & 74 & 38.5 \\
\hline & Grade6-8 & 114 & 59.4 \\
\hline & Grade9-10 & 4 & 2.1 \\
\hline \multirow[t]{2}{*}{ Literacy status } & Literate & 102 & 53.1 \\
\hline & Illiterate & 90 & 46.9 \\
\hline \multirow[t]{3}{*}{$\begin{array}{l}\text { Body mass } \\
\text { index }\end{array}$} & $\begin{array}{l}\text { Less than } \\
18.5 \mathrm{~kg} / \mathrm{m}^{2}\end{array}$ & 20 & 10.4 \\
\hline & $\begin{array}{l}18.6-24.9 \mathrm{~kg} / \\
\mathrm{m}^{2}\end{array}$ & 165 & 85.9 \\
\hline & $25-29.9 \mathrm{~kg} / \mathrm{m}^{2}$ & 7 & 3.6 \\
\hline \multirow{2}{*}{$\begin{array}{l}\text { Presence of } \\
\text { medical condi- } \\
\text { tions }\end{array}$} & Yes & 67 & 34.9 \\
\hline & No & 125 & 65.1 \\
\hline
\end{tabular}

A majority (45.8\%) were having an experience in brick industry for 16-25 years of duration of work. Also a majority of (79.2\%) of participants were working between 40-50 hours per week and only $1 \%$ of participants work between 61-75 hours. (Table 02) 
Table 02 occupational profile $(\mathrm{N}=192)$

\begin{tabular}{|l|l|l|l|}
\hline Characteristics & Categories & Frequency & $\begin{array}{l}\text { Percent- } \\
\text { age }\end{array}$ \\
\hline $\begin{array}{l}\text { Duration of work in } \\
\text { the brick industry }\end{array}$ & $2-5$ years & 11 & 5.7 \\
\hline & $6-15$ years & 62 & 32.3 \\
\hline & $16-25$ years & 88 & 45.8 \\
\hline $\begin{array}{l}\text { Duration of work } \\
\text { per week }\end{array}$ & 26-40 years & 31 & 16.1 \\
\hline & $51-60$ hours & 152 & 79.2 \\
\hline & $6-75$ hours & 2 & 19.8 \\
\hline
\end{tabular}

With regard to the frequency distribution of having pain or discomfort which lasting at least 24 hours during last 12 months, there were 126 participants (65.6\%) complained of having pain or discomfort which lasting at least 24 hours during last 12 months. There were only $32.3 \%$ of participants complained of having pain or discomfort which lasting at least 24 hours during last month. Also with regard to the frequency distribution of having pain or discomfort which lasting at least 24 hours during 7 days. There were only $3.1 \%$ of participants complained of having pain or discomfort which lasting at least 24 hours during last 7 days.(Table 03)

\section{Table 03 Duration of having pain $(\mathrm{N}=192)$}

\begin{tabular}{|l|l|l|l|}
\hline Characteristics & Categories & Frequency & Percentage \\
\hline $\begin{array}{l}\text { Having pain or } \\
\text { discomfort which } \\
\text { lasting at least 24 } \\
\text { hours during last 12 } \\
\text { months }\end{array}$ & Yes & 126 & $65.6 \%$ \\
\hline $\begin{array}{l}\text { Having pain or dis- } \\
\text { comfort which last- } \\
\text { ing at least 24 hours } \\
\text { during last month }\end{array}$ & Yes & 62 & $32.3 \%$ \\
\hline $\begin{array}{l}\text { Having pain or dis- } \\
\text { comfort which last- } \\
\text { ing at least 24 hours } \\
\text { during last 7 days }\end{array}$ & Yes & 6 & $34.4 \%$ \\
\hline & No & 186 & $96.1 \%$ \\
\hline
\end{tabular}

When considering the areas of pain or discomfort which lasting at least 24 hours during last 12 months, a majority of $65.87 \%$ reported as having low back pain, where $2.38 \%$ were having pain and discomfort in elbows and ankles/feet(Table 04).
Table 04 Areas of pain or discomfort

\begin{tabular}{|c|c|c|c|}
\hline Characteristics & Categories & Frequency & $\begin{array}{l}\text { Percent- } \\
\text { age }\end{array}$ \\
\hline \multirow{7}{*}{$\begin{array}{l}\text { Areas of having pain } \\
\text { or discomfort which } \\
\text { lasting at least } 24 \\
\text { hours during last } 12 \\
\text { months( } \mathrm{N}=126) \\
\end{array}$} & Neck & 4 & 3.17 \\
\hline & Shoulders & 12 & 9.52 \\
\hline & Elbows & 3 & 2.38 \\
\hline & Low back & 83 & 65.87 \\
\hline & $\begin{array}{l}\text { Wrists/ } \\
\text { hands }\end{array}$ & 14 & 11.11 \\
\hline & Knees & 7 & 5.55 \\
\hline & $\begin{array}{l}\text { Ankles/ } \\
\text { feet }\end{array}$ & 3 & 2.38 \\
\hline \multirow{8}{*}{$\begin{array}{l}\text { Areas of having pain } \\
\text { or discomfort which } \\
\text { lasting at least } 24 \\
\text { hours during last } \\
\text { month }(\mathrm{N}=62) \\
\end{array}$} & Neck & 6 & 9.7 \\
\hline & Shoulders & 7 & 11.3 \\
\hline & Elbows & 3 & 4.8 \\
\hline & low back & 18 & 29.0 \\
\hline & $\begin{array}{l}\text { Wrists/ } \\
\text { hands }\end{array}$ & 16 & 25.8 \\
\hline & $\begin{array}{l}\text { Hips/ } \\
\text { thighs }\end{array}$ & 1 & 1.6 \\
\hline & Knees & 8 & 12.9 \\
\hline & $\begin{array}{l}\text { Ankles/ } \\
\text { feet }\end{array}$ & 3 & 4.8 \\
\hline \multirow{5}{*}{$\begin{array}{l}\text { Areas of having pain } \\
\text { or discomfort which } \\
\text { lasting at least } 24 \\
\text { hours during last } 7 \\
\text { days }(\mathrm{N}=6)\end{array}$} & Neck & 1 & 16.6 \\
\hline & Shoulders & 2 & 33.3 \\
\hline & Elbows & 1 & 16.6 \\
\hline & Low back & 1 & 16.6 \\
\hline & $\begin{array}{l}\text { Wrists/ } \\
\text { hands }\end{array}$ & 1 & 16.6 \\
\hline
\end{tabular}

Among the workers who were having musculoskeletal pain or discomfort which lasting at least 24 hours during last 12 months there was no any significant difference between age groups and gender with presence of musculoskeletal of pain or discomfort(Figure $01 \&$ 02) 


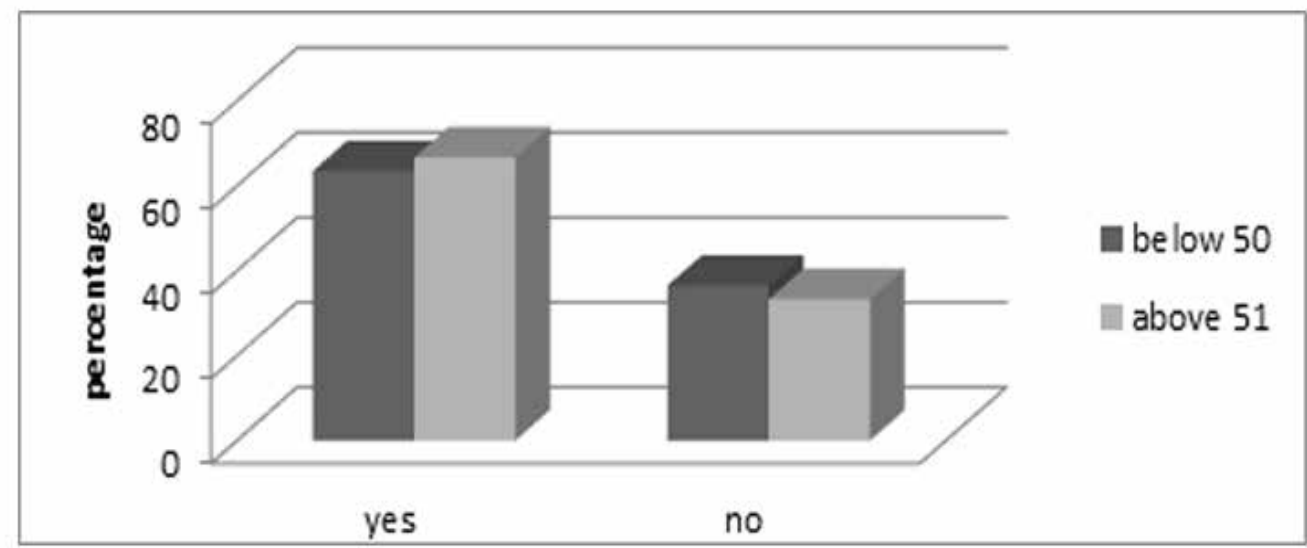
Figure 01. Presence of musculoskeletal of pain or discomfort which lasting
at least 24 hours during last 12 months with gender

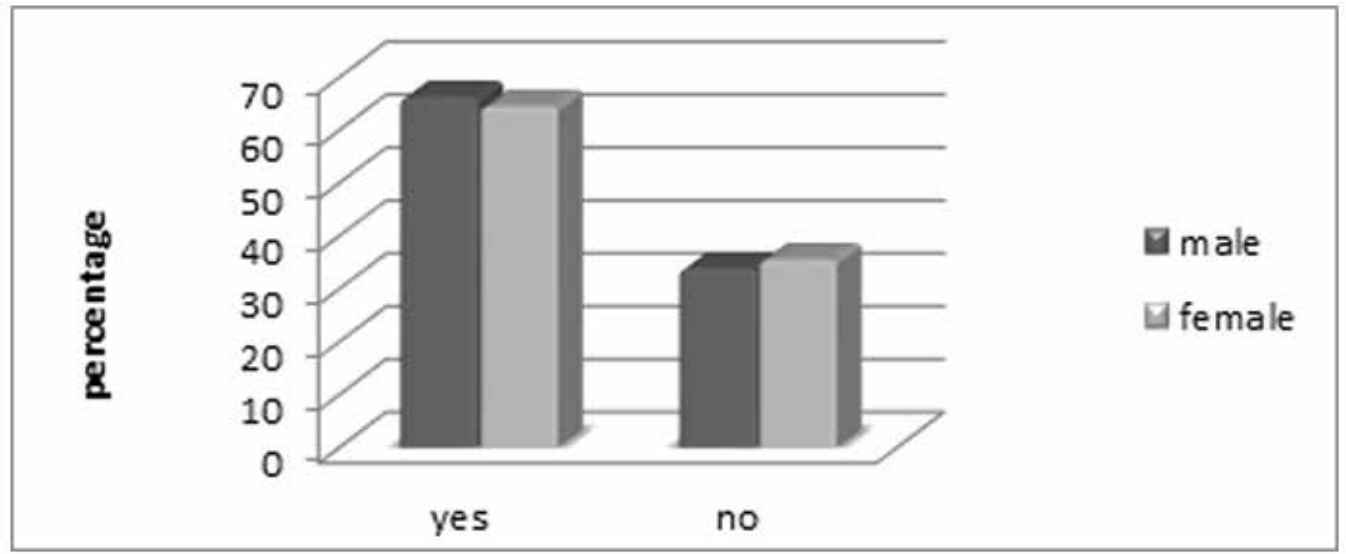

Figure 02.Presence of musculoskeletal of pain or discomfort which lasting at least $\mathbf{2 4}$ hours during last $\mathbf{1 2}$ months with age groups

Among them; a majority (82.5\%) were prevented from doing the normal work activities at home or away from home because of a musculoskeletal pain or a discomfort. When considering the methods used to relieve pain or discomfort a majority (77.0\%) of participants applies a local analgesic to relieve the pain where $13.5 \%$ of the participants do nothing with their pain, but rest. When considering taking any drugs without a doctor's prescription to relieve pain or discomfort, it was obvious that $54.7 \%$ of the participants take drugs without a doctor's prescription and the drug that they were taking was Paracetamol. Moreover during the brick making process $27.0 \%$ of workers are holding load at a distance as a majority. Twisting of the trunk is also a considerable task where $23.8 \%$ of the workers are engaged in. Majorities (73.8\%) of workers were lifting the load manually and majorities (67.5\%) of workers were working in a limited working environment. At the same time most of the workers $(67.5 \%)$ were working in an uneven working environment and a least of (5.5\%) workers were working at the extremes of temperature. There were $44.4 \%$ of the participants using bidi. And $21.4 \%$ of the workers used to chew betel during the day time.( Table 05) 
Table 05 Nature of the working surrounding

\begin{tabular}{|c|c|c|c|}
\hline Characteristics & Categories & Frequency & $\begin{array}{l}\text { Percent- } \\
\text { age }\end{array}$ \\
\hline \multirow[t]{2}{*}{ Preventing from normal work activities } & Yes & 104 & 82.5 \\
\hline & No & 22 & 17.5 \\
\hline \multirow[t]{3}{*}{ Methods using to relieve pain or discomfort } & Local analgesic application & 97 & 77.0 \\
\hline & Fermentation & 12 & 9.5 \\
\hline & None & 17 & 13.5 \\
\hline \multirow{2}{*}{$\begin{array}{l}\text { Taking any drugs without a doctor's prescription to relieve pain } \\
\text { or discomfort }\end{array}$} & Yes & 69 & 54.7 \\
\hline & No & 57 & 45.3 \\
\hline \multirow[t]{8}{*}{ The specific tasks that the workers are engaged in } & Holding load at a distance & 34 & 27.0 \\
\hline & $\begin{array}{l}\text { Unsatisfactory bodily move- } \\
\text { ment/posture }\end{array}$ & 24 & 19.0 \\
\hline & Twisting of the trunk & 30 & 23.8 \\
\hline & Stooping & 5 & 3.9 \\
\hline & Excessive movement of load & 1 & 0.8 \\
\hline & Excessive carrying distances & 4 & 3.1 \\
\hline & $\begin{array}{l}\text { Frequent or prolonged } \\
\text { physical effort }\end{array}$ & 24 & 19.0 \\
\hline & $\begin{array}{l}\text { Handling that goes on for } \\
\text { too long without a break }\end{array}$ & 4 & 3.1 \\
\hline \multirow[t]{3}{*}{ Methods of lifting the load } & Lifted manually & 93 & 73.8 \\
\hline & $\begin{array}{l}\text { Awkward grasping of the } \\
\text { load }\end{array}$ & 17 & 13.5 \\
\hline & $\begin{array}{l}\text { Awkward location of load at } \\
\text { onset or end of lifting }\end{array}$ & 16 & 12.5 \\
\hline \multirow[t]{2}{*}{ Limitation of the work environment or work materials } & Yes & 85 & 67.5 \\
\hline & No & 41 & 32.5 \\
\hline \multirow[t]{4}{*}{ condition of the working environment } & Uneven & 85 & 67.5 \\
\hline & Slippery & 26 & 20.6 \\
\hline & Unstable floor & 8 & 6.4 \\
\hline & Extremes of temperature & 7 & 5.5 \\
\hline \multirow[t]{4}{*}{ usage of substances } & Cigarettes & 14 & 11.1 \\
\hline & Bidi & 56 & 44.4 \\
\hline & Arrack & 29 & 23.0 \\
\hline & Betel & 27 & 21.4 \\
\hline
\end{tabular}




\section{Discussion}

WMSDs have become a social issue all around the world. The consequences of WMSDs are discussed on many aspects which can be mentioned briefly as reduced production, loss of income and diminished quality of life because of the disturbances to the activities of daily living hence by leading to a slow economic growth. Results on the researches on brick industry shows that the workers reported as having pain or discomfort arising from work, the body regions most commonly affected were low back, wrists, hands, shoulders, and knees. Researchers have shown that this pain or discomfort is related with unfavorable postures that the workers are exhibiting during entire the process of brick making.

Brick workers who comprise a large part of the unorganized work sector in rural areas of Sri Lanka are in a disadvantageous position and literature regarding their health problems and needs are largely unavailable. This study was done with a aim of assessing the prevalence of WMSDs among brick industry workers in Chilaw area, Puttlam District to identify the most affected body regions and the joints in the body and ergonomic risk factors in the work place and to explore associated factors of WMSDs, as well as to identify the effect of musculoskeletal disorders to their activities of daily living.

In this study there were 192 brick industry workers who were in the field for more than 1 year where there was a male predominance of $67.7 \%$. A major proportion (72.9\%) of the participants was belonged to the $41-60$ age categories which show large engagement of the elderly population. The participants ages ranged from 22 to 70 with the mean of $51.54(S D=10.344)$ years. In the study sample a majority (87.5\%) was Sinhalese and educational attainment was uniformly low where only $2.1 \%$ of the participants were in the grade 9-10 category. Most of them (59.4\%) were studied below grade 8 . This interprets that low educational status is leading people to occupations like this. Most of the workers have a good experience on the brick industry as majority (45.8\%) was in the 16-25 years of duration of work category. Meantime their BMI was relatively normal as majority (85.9\%) were normal weighed. However these workers have no coverage of social security and have to spend out of their whole incomes for all contingencies such as illnesses and children's education and in their old age they are helpless. At the same time the workers are self-employed, and brick industry is a cottage industry in these rural areas, where the entire family is involved to sustain their livelihood because the materials are getting from their own lands which leads to collection of water near by their houses and it is also can cause other health problems like providing a source for vector breeding, and can result in domestic injuries specially to children. However in some unorganized settings workers were getting material from the lands near by the rivers which lead to an environmental issue too. However the workers always had a complaint that they were in a huge problem in finding the materials, especially clay.

When considering the musculoskeletal symptoms, there were multiple paining areas among the workers, but in this study is focused on the most worsen region of pain. Among the participants of this study there were a majority of $65.6 \%$ participants complained of having pain or discomfort which lasting at least 24 hours during last 12 months and when considering the areas of pain or discomfort among them, a majority of $65.87 \%$ reported as having low back pain, $11.11 \%$ on wrists/hands, $9.52 \%$ on shoulders, $5.55 \%$ on knees, $3.17 \%$ on neck, $2.38 \%$ on elbows, ankles/feet. One month prevalence of pain and discomfort was $32.3 \%$ where prevalence of low back pain was $29.0 \%$ and prevalence of hands or wrists pain was $25.8 \%$. One week prevalence of low back pain was $16.6 \%$. However a study carried out Das B(2014) in India has shown that brick field workers suffered from pain especially in the lower back(98\%), hands(93\%), knees $(86 \%)$, wrists(85\%) which is much differ from this study. But it is concluding that in this study brick industry workers suffers from pain or discomfort in different body regions of the body, especially the lower back, wrists/ hands, shoulders, knees, neck, and ankles/feet and elbows.

An evaluation of pain among female brick workers of West Bengal, India showed that $70 \%$ of the female workers reported pain [6] and similarly my study reveals that $64.5 \%$ of the females were having pain.

Another study carried out in South Africa[7] has shown that $78.95 \%$ of the employees indicated as they have been prevented from normal activities because of pain. With regard to this study $82.5 \%$ of the workers were prevented from normal work activities because of pain which is also similar. So it is obvious that these MSDs affect the workers activities of daily living.

Moreover material handling is a cheapest solution in developing countries and most of the brick workers mainly perform such handling. In this study majority $(73.8 \%)$ of the workers who have the pain or discomfort lift the load manually. To avoid MSD, this study suggests decreasing the physical load of the workers and carrying the brick and clay in a trolley. According to the workers extremely demanding process which the subjects felt discomfort was clay modifying. Thus highly forceful work may be regarded as a causative factor for the development of MSDs in brick workers. 
Among the workers who perceived pain or discomfort $77 \%$ were applying a local analgesic to relieve their pain which is easily accessible in shops. A large proportion (54.7\%) was taking drugs over the counter for relieving the pain. But $13.5 \%$ of the workers do nothing with their pain but rest. Moreover the nature of the workplace can also be contributing to the MSDs because $67.5 \%$ of workers who have musculoskeletal pain or discomfort were working on a limited environment and in an uneven surrounding. When considering the substance usage, most commonly used substance was bidi (44.4\%) among the pain presented workers and $21.4 \%$ was used to chew betel during the working time which shows that the workers are from the low socio economic status. The influence of payment method for the workers increases fast working as the workers earn money depending on how many bricks they make and not how many hours they work. In most places workers are targeted on making 1500-2000 bricks per day which requires high frequency. This contributes to the forceful and high frequency working that can result in MSDs. And the other thing is, according to their payment method, the work force in one unit is limited for 2-3 and workers more than 3 in one unit was not found during the entire study. This factor contributes to heavy work load and these limited workers are required to perform each and every simple task to the most difficult tasks without any delegation until the end of the entire process. At the same time as they are focused on the number of bricks they are not interested in taking breaks. More often they work for about 10 hours per day while taking only one hour break.

\section{Conclusion}

WMSDs are prevalent among brick industry workers who are in the industry for more than 1 year. The most commonly affected body regions and joints in the body are low back, wrists/hands, shoulders, knees, neck, elbows and ankles/feet. The ergonomic risk factors that can present in the work place includes specific actions during the process of brick making, such as holding load at a distance, unsatisfactory bodily movement/posture, twisting of the trunk, and frequent or prolonged physical effort. There is no any significant difference with the age and sex with the presence of musculoskeletal discomfort or pain. These MSDs are affecting the activities of daily living of these workers by preventing from doing normal work activities.

\section{References}

1. Punnett L. Work-related musculoskeletal disorders: The epidemiologic evidence and the debate. J Electromyogr Kinesiol. 2004;14:13-23

2. World Health Organization, [internet]. (cited 2016 Sep 21 ).Available from

3. Alex R. (2013) Prevalence of musculoskeletal disorders among brick kiln workers in rural Southern India. Indian J Occup Environ Med. 2013; 17(2):71-75.

4. Mani L, Gerr F. Work-related low back pain, Prim Care. 2000; 27(4):865-876.

5. Kuorinka, I. Standardized Nordic questionnaires for the analysis of musculoskeletal symptoms. Applied ergonomics.1987;18(3):233-237

6. Das B. An evaluation of low back pain among female brick field workers of West Bengal, India. Environ Health Prev Med.2015;20(5):360-368.

7. 7Ndivhudzannyi, E.M. The Study of Work-Related Musculoskeletal Disorders Amongst Workers in Brick Making Factory in South Africa, [internet]. Human work sciences;2003(cited 2016 Sep 21 ). Available from: 